\title{
陸水物理研究会 2018年大会の報告
}

\author{
知北 和久 ${ }^{1 *}$ \\ Report on the 2018 annual conference of \\ the Japanese Society of Physical Hydrology
}

\author{
Kazuhisa A. CHIKITA ${ }^{1 *}$
}

陸水物理研究会の 2018年度（第 40 回記念）全 国大会は，2018年11月16日 (金)～18日 (日)に 石垣市の大濱信泉記念館・多目的ホール（世話 人: 国際農林水産業研究センター, 飯泉佳子氏) で開催された。11月16日は国際農林水産業研究 センター主催 (陸水物理研究会協賛) によるサ テライト・ワークショップ “Sustainable Resource Management and Environmental Conservation in Pacific Islands”が行われた。続い て, 11 月 17 日は陸水物理研究会主催 (八重山陸 水研究会と地球惑星科学連合・大気水圈科学セク ションの協賛）の研究発表会と公開シンポジウム 『島嶼に打ける水環境と自然災害一北海道から八 重山諸島まで一」, 11月18日は巡検が実施され た。参加者総数 49 名, 研究発表 27 件（口頭 20 件, ポスター 7 件), 巡検参加者 27 名であった。 以下に，11月 17 日の発表プログラムを記す。な お, 本大会の学生優秀発表賞として, 学生発表 5 件の中から 9）の堀内雅生氏 (法政大学) が表彰 された。

今回の第 40 回記念大会を機に,「陸水物理研究 会」は「陸水物理学会」と改称し, 原則年一回の 「陸水物理学会誌」を発行することとなった。な お, 英語名とロゴは従来通りである。詳しくは, ホームページ http://jsph.sub.jp/をご覧ください。
11 月 17 日 (土) 陸水物理研究会研究発表会

〈頭発表〉

1）飽和面からの蒸発量を推定する表面ボーエン 比法 (SBR法) の検証

浦野愼一（NTCインターナショナル株式会 社), 酢谷 岳 (富山県庁)

2) 水による光吸収が湖底での乱反射および湖内 での光散乱に加わる場合の湖沼の青色呈色の 試算 : 光物理の立場からの一考察

花石竜治（青森県環境保健センター）

3） 2011 年紀伊半島豪雨 赤谷・長殿崩壊メ力 ニズムの再検討

齊藤隆志（京都大・防災研究所）

4）地表水-地下水相互作用と生態系影響：地下 水が沿岸環境の多様性形成に及ぼす影響に着 目して

齋藤光代 (岡山大·院・環境生命), 小野寺 真一 (広島大·院・総合科学), 岩田 徹 · 大久保賢治 (岡山大・院・環境生命)

5）流域における水循環に駆動されるリンおよび 窒素循環の未知一生態系ストックと動態つ ロー

小野寺真一 (広島大 · 院 - 総合科学), 齋藤 光代 (岡山大 · 院 · 環境生命), 清水裕太 (農研機構), 福岡正人 (広島大), 田瀬則雄 (筑波大)

6）地震による地盤の水理特性の変化とその回復

1 北海道大学 大学院理学院 地球惑星科学部門 Department of Earth and Planetary Sciences, Faculty of Science, Hokkaido University

* 責任著者 
知北

について

北岡豪一・西村敬一・山下栄次（岡山理科 大)

7）火山性深湖に打ける地殼熱流量評価一摩周 湖・俱多楽湖・田沢湖の比較一 知北和久 (北大·北極域セ)，大八木英夫 (日大・文理)，田中 敦 (国立環境研)，網 田和宏（秋田大 - 理工），藤井智康（奈良教 育大）

〈ポスター発表〉

8）草津白根山周辺地域の水環境に関する研究 (3)

猪狩涁寛（法政大・院），小寺浩二（法政 大・地理)，浅見和希（法政大・院）

9）箱根山周辺の水環境-噴火（150629）後を中 心に (3)

堀内雅生 (法政大・学), 小寺浩二 (法政 大・地理)，猪狩涁寛（法政大・院），浅見和 希（法政大・院）

10）長崎県島嶼の河川水質特性（2） 矢巻 剛 (法政大・院), 小寺浩二（法政 大・地理），浅見和希（法政大・院），猪狩涁 寛 (法政大・院)，堀内雅生（法政大・学)

11）御获山噴火後の高山湖沼及び周辺諸河川の水 質変化 (3)

浅見和希（法政大・院），小寺浩二（法政 大・地理)，猪狩涁寛（法政大・院），堀内雅 生 (法政大·学)

12) SWAT model analysis for the effect of crop growth on sediment yield from a settling basin catchment in Ishigaki island Yang Cao, Shin-ichi Onodera (Hiroshima Univ.), Mitsuyo Saito (Okayama Univ.), Hide Omae, Yoshiko Iizumi (JIRCAS)

13）北海道東部の森林小河川における河川流量と フラックス

鎌内宏光 (地球研), 福島慶太郎 (京大・生 態研), 近藤昭彦 (千葉大・環境リモセン), 岡部芳彦・勝山智憲・佐藤修一・林 大輔
徳地直子 (京大・フィールド)

14）熊本県菊池川流域におけるSWAT モデルを 用いた森林の流出機構の推定

藤井創一朗，金森匡彦，永野裕子（(一社) 日本森林技術協会)，木下 牧（(株) パス コ), 清水裕太 (農研機構西日本農業研究七 ンター), 小野寺真一 (広島大)

\section{〈口頭発表〉}

15）田沢湖深層部にみられる水温の上昇

林 武司 (秋田大・教育文化)，石山大三 · 小川泰正（秋田大・国際資源）

16）臨界水深概念の前提としての混合水深の実用 的評価手法について

古里栄一（鹿児島大・南九州・南西諸島共創 機構), Tulaja Gurung（埼玉大院・理工）, 鮎川和泰 (環境システム), 中山恵介（神戸 大・工)，清家 泰（島根大・エスチュア リーセンター), 今本博臣（水機構・総技セ ンター), 久納 誠 (水機構・総技セン タ一)，前田広人（鹿児島大 ·水産），奥西将 之 (鹿児島大 ·水産), 伊藤祐二（鹿児島 大・農)

17）沖縄県石垣島河川水質の栄養塩特徵とアンパ ルマングローブ林内水温変動

干川 明（NPO 法人石西礁湖サンゴ礁基 金／八重山陸水研究会）

18）扇状地河川の伏没帯における地中熱利用の可 能性

阪田義隆（北大·工），葛隆生（北大 · 工)，長野克則（北大·工）

19）別府群発地震時の温泉水位について 柴田智郎 (京都大・理・地球熱学研究施設)

20）暑熱地域における園芸施設の室内熱環境のシ ミュレーションと評価 葛 隆生，鈴木大也（北大・工）

21）河床䃇の粒径分布分析を用いた岡山・旭川中 流域の河床調查 山口一裕（岡山理科大） 
〈公開シンポジュウム：島嶼における水環境と自 然災害一北海道から八重山諸島まで一

22）島嶼地域の水環境の把握と保全のための産官 学民の連携

小寺浩二 (法政大・地理), 浅見和希·矢巻 剛・猪狩彬寛（法政大・院），堀内雅生（法 政大・学)

23）水資源として重要な山岳地域の雪 鈴木啓助（信州大・理）

24）北海道の $3 \sim 5$ 月に打ける最近の雪水災害 石井吉之 (北大・低温研)

25）屋久島 1979 ，三宅島 $2000 ， そ し て$ 伊豆大島 2013 土石流災害に学ぶ

諏訪 浩（東大・空間情報科学研究センタ, 立命館大・歴史都市防災研究所）

26）海と陸とを一体的に捉えた島嶼型統合的水循 環管理を目指して

安元 純 · 野崎真司 - Bam HN Razafindrabe (琉球大 ·農), 中屋真司（信州大 · 工), 土岐知弘・新城竜一 (琉球大・理), 安 元 剛 (北里大 ·海洋生命)

27）西南日本亜熱帯島しょの陸水環境と沖縄の 島々に打ける上水道供給方法 東田盛善 (八重山陸水研究会) 総合討論

11月 18 日 (日) : 巡検「石垣島・竹富島をめぐる 旅と天体観望会」

巡検案内者 : 飯泉佳子氏 (国際農林水産業 研究センター)

巡検 1 : 石垣港離島ターミナル (Photo 1) $\rightarrow$ 国際農研 熱帯・島嶼研究拠 点 (Photo 2) $\rightarrow$ 沈砂池 (Photo 3)

巡検 2 : 石垣港離島ターミナル $\rightarrow$ 竹富島（水牛車 Photo 4, 自由散策Photo 5) $\rightarrow$ 石垣港離 島ターミナル (Photo 6)

巡検 3 : 石垣島天文台・天体観望会（天王星, 月 のクレーター，火星の観察；Photo 7)

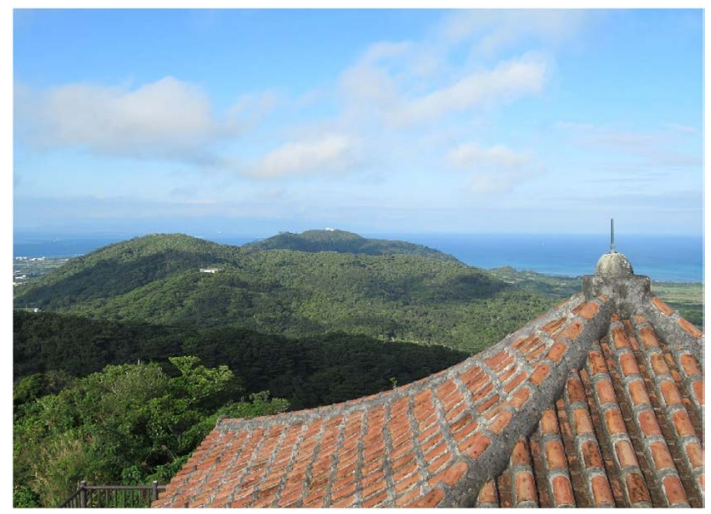

Photo 1 バンナ展望台から見た「高島」である石垣島 の山稜と海岸線.

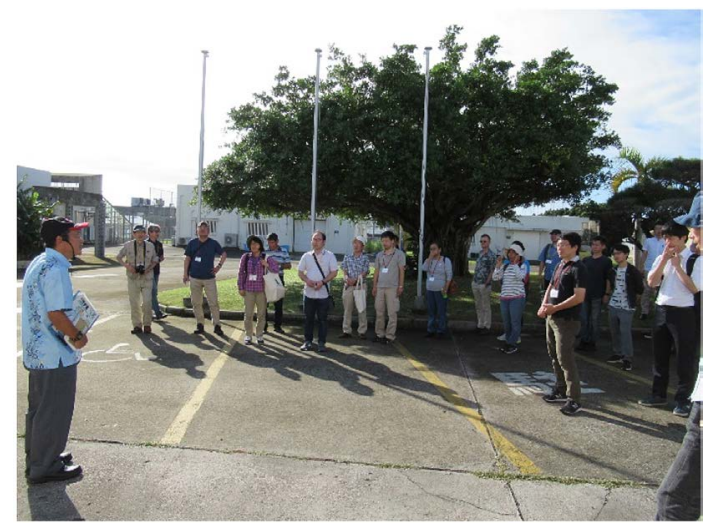

Photo 2 国際農研 熱帯・島嶼研究拠点の見学 (左 が案内をしてくれた大前所長).

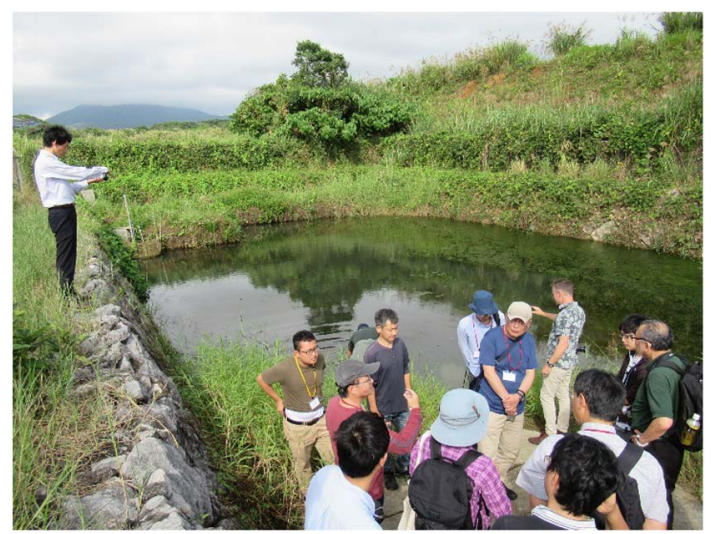

Photo 3 島内にある沈砂池の見学. 
知北

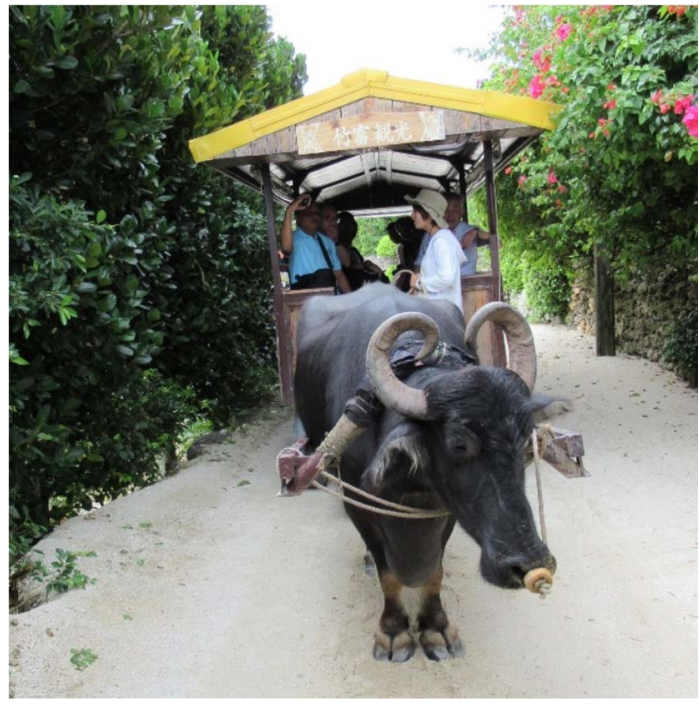

Photo 4 竹富島の水牛車.

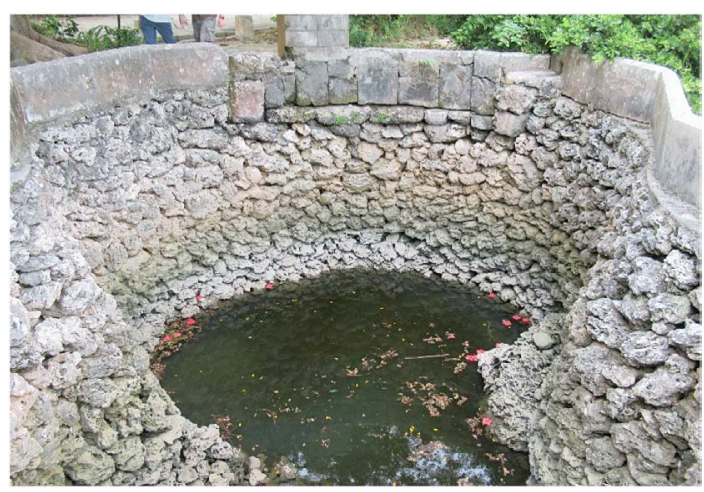

Photo 5 竹富島の井戸（湧水点の発見は室町期とさ れる)。

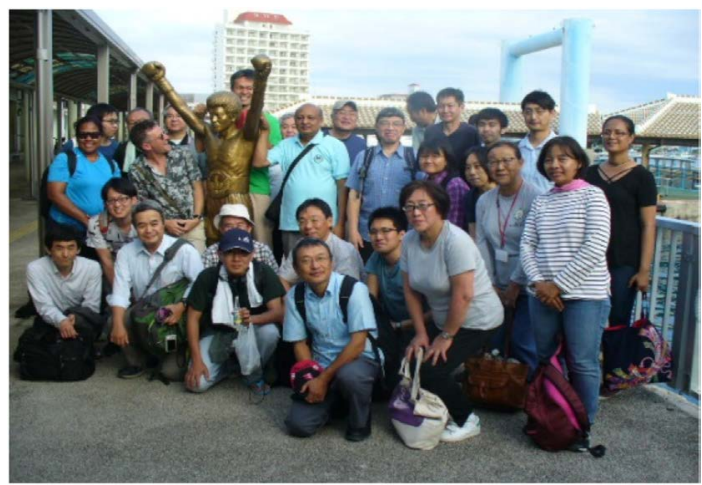

Photo 6 離島ターミナルでの集合写真.

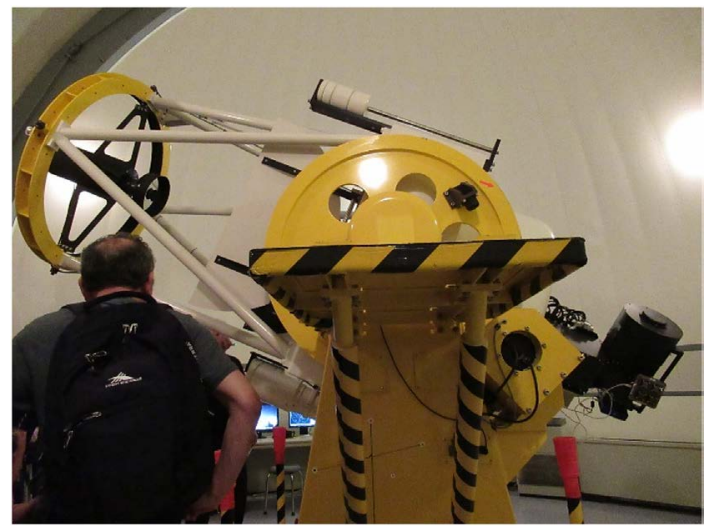

Photo 7 石垣島天文台にある口径 $105 \mathrm{~cm}$ のむりか ぶし望遠鏡”で天王星などを観察。

- 陸水物理学会 2019 年度（第 41 回）松本大会 (予告)

日 時：2019年 11 月 9 日 (土) 10日 日)

場 所 : 信州大学理学部 (長野県松本市)

世話人：鈴木啓助氏（信州大）

11月9日：研究発表会

11月 10 日：巡検 